\title{
Transition to adulthood in Latin America: 1960s-2010s
}

\author{
Matheus Menezes dos Santos* \\ Bernardo Lanza Queiroz ${ }^{* *}$ \\ Ana Paula de Andrade Verona ${ }^{\star \star *}$
}

Multidimensional discussion about transition to adulthood is an incipient theme in Latin America. This paper seeks to describe and characterize the process of change in the transition of men and women in the region between the 1960 s and 2010 's. Using census data from IPUMS-International for 15 Latin American countries, we calculate the mean ages at transition to adulthood, at entering the labor market, at first union, and at first birth. We concluded there was a process of postponing transition to adulthood, although much stronger for males than for females, which we attribute to the events linked to the transition of each group. With these results, we hope to encourage further research into transition to adulthood in Latin America.

Keywords: Transition to adulthood. Latin American youth. Mean age at entry in the labor market. Mean age at the first union. Mean age at the first birth.

\footnotetext{
* Centro de Desenvolvimento e Planejamento Regional (Cedeplar), Universidade Federal de Minas Gerais (UFMG), Belo Horizonte-MG, Brazil (matheus.menezes@hotmail.com.br; https://orcid.org/0000-0002-8164-61-82).

** Centro de Desenvolvimento e Planejamento Regional (Cedeplar), Universidade Federal de Minas Gerais (UFMG), Belo Horizonte-MG, Brazil (lanza@cedeplar.ufmg.br; https://orcid.org/0000-0002-2890-1025).

${ }^{* \star *}$ Centro de Desenvolvimento e Planejamento Regional (Cedeplar), Universidade Federal de Minas Gerais (UFMG), Belo Horizonte-MG, Brazil (anapaula@cedeplar.ufmg.br; https://orcid.org/000-0002-2062-9194).
} 


\section{Introduction}

Transition to adulthood has been an important research topic in sociology for decades in developed countries (BILLARI; HIEKEL; LIEFBROER, 2019; BILLARI; LIEFBROER, 2010). Social scientists study the topic to understand changes in the process of leaving the parental family and forming a new family, mainly from cohorts born after WWII. These processes are the sequence of events that begins with the end of formal education, entering the job market, and leaving the parental home, evolving into marriage and parenthood. The general conclusion is that young adults have spent more time connected to the parental family and have delayed the formation of their own family, which can be summarized as a postponement of the transition to adulthood (BUCHMAN, 1989; CORIJN; KLIJZING, 2001).

There are fewer studies about transition to adulthood in less developed economies with different cultural backgrounds (GRANT; FURSTENBER, 2007). Latin America is a special and interesting case to study because the region has social, economic and cultural characteristics different from those of developed countries. Fussel and Palloni (2004) and Heaton et al. (2002) show that the mean age at first union and at first child has remained stable on the continent in recent decades, while in Europe, Corijn and Klijzing (2001) and Billari (2004) show that young adults have postponed their family formation. Another important factor is the increasing educational level and economic modernization in Latin America, which might be a process leading to postponement of transition to adulthood by raising opportunity costs of early transitions (LLOYD, 2005).

The brief research note provides an overview of the changes in transition to adulthood for several countries in Latin America in recent decades by calculating the mean age at the transition to adulthood using census data. We situate the Latin American context in the literature on the transition to adulthood, highlighting specific characteristics of the region and pointing to more in-depth studies on countries and population subgroups on the continent and suggesting some research questions to deepen our knowledge in this context.

\section{Data and methodology}

Modell et al. (1976) present an important methodological approach for the study of the transition to adulthood. It is based on the concept of social psychology whereby the individual becomes an adult when society sees him/her as such, defining the transition as the passage through events to assume social roles typical of adults. In other words, the young person becomes an adult when they assume the role of worker, husband/wife, parent, or when they leave the parental home. Once it is possible to identify whether the individual has gone through any of these transitions, it is possible to identify whether the individual is an adult or not. By using this adulthood identifying criterion, despite its conceptual limitations, it is possible to obtain the proportion of adult individuals by age and sex in each census. Then, we use these proportions to estimate the mean age at the transition 
to adulthood using the Singulate Mean Age at First Marriage (SMAFM) method presented by Hajnal (1953). The method is an alternative for calculating life expectancy when there are no data on transition rates that would allow the construction of a traditional lifetable (WACHTER, 2014). Proposed for the study of nuptiality patterns in historical populations, it is still widely used today for contexts of lack of data on transitions (FUSSEL; PALLONI, 2004; ESTEVE et al., 2013, for example).

TABLE 1

Census data of Latin America available in the IPUMS

\begin{tabular}{ll}
\hline Argentina & $1970,1980,1991,2001$ \\
Bolivia & $1976,1992,2001$ \\
Brazil & $1960,1970,1980,1991,2000,2010$ \\
Chile & $1970,1982,1992,2002$ \\
Colombia & $1973,1985,1993,2005$ \\
Costa Rica & $1973,1984,2000,2011$ \\
Ecuador & $1974,1982,1990,2001,2010$ \\
Guatemala & $1981,1994,2002$ \\
Honduras & $1974,1988,2001$ \\
Mexico & $1990,2000,2010$ \\
Nicaragua & $1971,1995,2005$ \\
Panama & $1960,1970,1980,1990,2000,2010$ \\
Paraguay & $1962,1972,1982,1992,2002$ \\
Uruguay & $1963,1975,1985,1996,2006,2011$ \\
Venezuela & $1971,1981,1990,2001,2012$ \\
\hline
\end{tabular}

Source: IPUMS (2020)

Table 1 presents the list of countries and censuses years used in the analysis. We used all countries with at least three censuses available. To identify the transition to adulthood, we focused on questions that capture, or at least approximate, the identification of a transitioned individual by each possible event, and are widely available in various demographic censuses in the region. To facilitate cross-national comparison, we use the standardized variables created by the IPUMS (Integrated Public Use Microdata Series) from the original microdata from the censuses of Latin American countries:

- LABFORCE: shows the status of the individual's participation in the labor market. Although it does not directly capture whether the individual has ever worked or not since one can leave and enter the job market several times, this variable brings a good approximation when it comes to the young population.

- MARST: individual's marital status. It is possible to identify the individual who has already been through the complement of the category "single/never married".

- NCHILD: the number of children of the individual at home, a proxy to identify who has already transitioned to parenthood (if the number of children is higher than zero). This variable does not capture how many children born alive the individual had since the child may not be at home or have died before the census' reference 
date. As this paper focuses on the young population, it is expected that the children are younger and, therefore, live with their mothers. We ignore this variable for men since it is not possible to be sure of the paternity of children assigned to them by the IPUMS algorithm.

- RELATED: through the individual's relationship with the head of the household, it is possible to identify who does not live with parents or any other family member. Again, it is not an absorbing state variable, since the individual can leave and return to the parental home, but we believe it is a good approximation.

- ADULT: It is a variable created by the authors. If the person has gone through at least one of the transitions (identified here by the variables LABFORCE, MARST, NCHILD, and RELATED), the person is then classified as an adult.

It should be noted that there may be problems with the census data, even after treatment by IPUMS. Variables such as number of children and marital status can have their results altered by changes in the way of asking between one census and another. However, it is still the best source of data for several countries in Latin America for the variables used in this paper.

An analysis of the quality of the data for each variable, each country, and each census year is a work far beyond what is intended in this note. In previous analyses, no alarming discrepancies were noted. We then chose to report the results as calculated directly from the IPUMS data, relying on an expected good quality of the information after decades of consistent use of that data source.

\section{Results}

Figure 1 shows the changes in mean age at transition to adulthood, mean age at entry into the labor market, and mean age at first union among men in Latin America by census' round. We observed an increase in the mean age at transition to adulthood for males in all countries in recent decades, or in other words, a consistent postponement of transition to adulthood in the region. But there are some important regional differences: transition to adulthood in Colombia, the oldest age in the 2000 s round, is 2.05 years greater than in Nicaragua, the lowest age in the same census' round.

The postponement of transition can be explained by the increase in the schooling of young Latin Americans from the 1960s (NEIDHÖGER; SERRANO; GASPARINI, 2018; ESTEVE et al., 2013). The idea is that this increase could lead to the postponement of transition to adulthood through two mechanisms (BUCHMAN, 1989; CORIJN; KLIJZING, 2001). The first is that the increase in the schooling period would lead to the postponement of transitions such as entering the labor market due to the simple difficulty of reconciling work and school; the second is that the increase in schooling would lead to an increase in the human capital 
of young Latin Americans, thus also increasing their opportunity cost to enter the labor market early or to form a family prematurely.

\section{FIGURE 1}

Mean age of men at transition to adulthood, at entry into the labor market, and at the first union Latin America countries -1960-2010

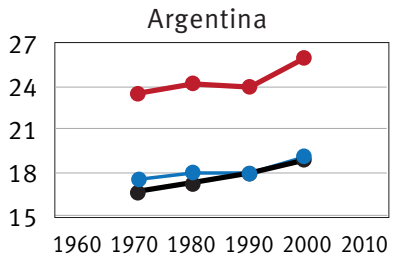

Chile
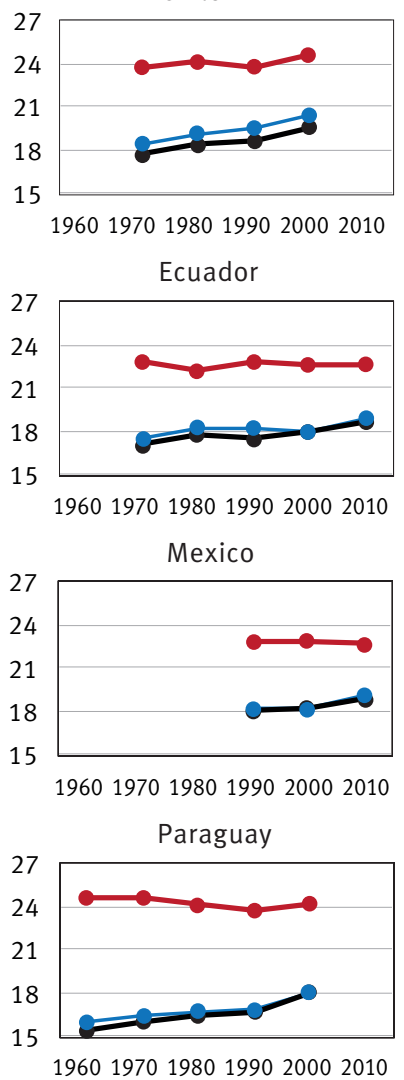

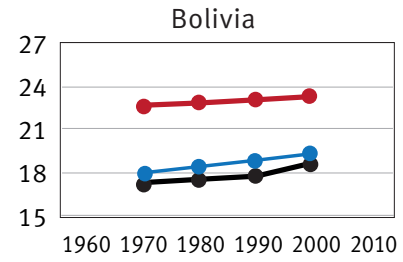

Colombia

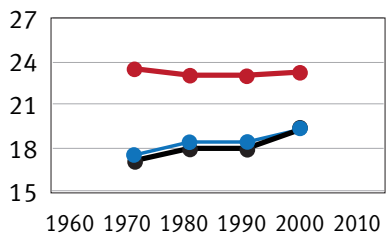

Guatemala
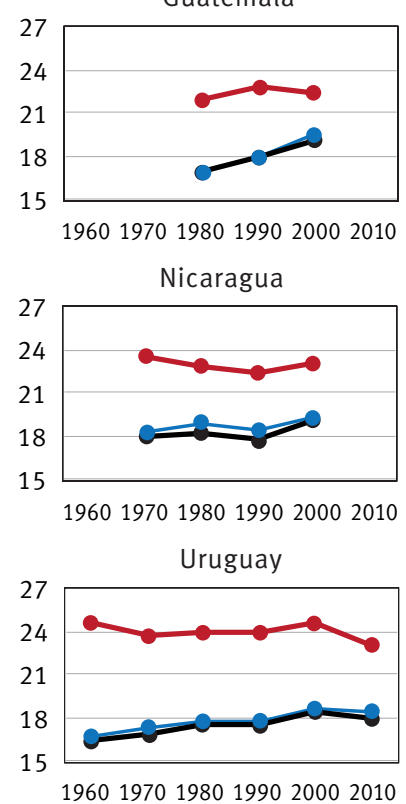

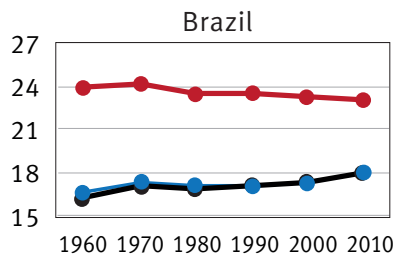

Costa Rica
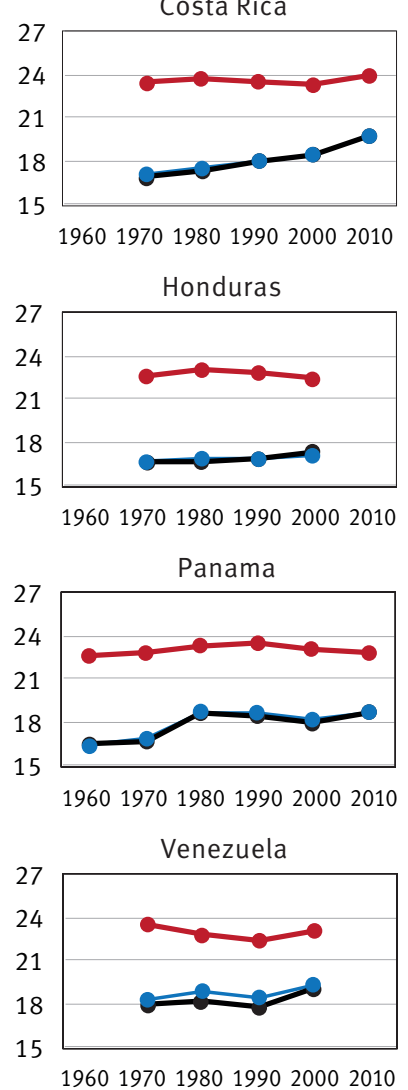

Mean age at transition to adulthood $\longrightarrow$ Mean age at entry into labor market

$\longrightarrow$ Mean age at first union

Source: IPUMS (2020).

The results suggest that the adulthood transition of men is strongly determined by entering the labor market, given the extremely high correlation between both transitions. One hypothesis to explain this result is that there is pressure for men to assume the role 
of bread-winner within families, which may lead them to choose to enter the labor market only to form a family later, after having an income to do so.

Despite being part of the calculation of the mean age at transition to adulthood, the mean age at leaving home is not shown in this paper because it would be redundant: this measure coincides exactly with the mean age at first union because leaving parental home in Latin America is an event led almost exclusively by marriage.

Figure 2 shows the transitions for women in the same countries and periods. In this case, we also include the transition to having the first child. We found greater stability of mean age at the transition to adulthood over the past few decades compared to men. In some countries, such as Brazil, there was even an inversion: men transitioned earlier than women in 1960 (16.24 years against 18.30 years) but started transitioning later in 2010 (17.92 years against 17.86 years). Moreover, it is notable that the transition of women appears not to be as strongly defined by entry into the labor market, as is the case with men.

It is important to note that the mean age at entry into the labor market in the $1960 \mathrm{~s}$ and 1970 s may be due to a bias in the SMAFM method: there was a very rapid change in the age structure of females in the labor market, which affects the assumption of the stability method (or quasi stability), necessary for the interpretation of the results as a hypothetical cohort. However, it is possible that mean age at entry into the labor market for females is lower than that of males because a considerable part of Latin American females works in paid domestic service, which tends to accept very young workers (BARROS et al., 2001).

The stability of mean age at first union over the decades, both for men and women, confirms the results from Fussel and Paloni (2004), despite the increase in schooling. Esteve et al. (2013) explain this stability by increasing informal unions, which are historically younger than formal unions. Informal union in Latin America is strongly associated with lower socioeconomic status due to lower costs and the distance from legal institutions, in contrast to the informal union in the European context, which is associated with higher social classes due to greater degrees of modernity and secularization (ESTEVE et al., 2013; VERONA et al., 2015). Lesthaeghe (2020) argues that part of the increase in informal unions among more educated women is due to more modern patterns of union, but that in particular for Latin America the role of economic vulnerability and cultural inheritance is stronger.

The mean age at the first child follows the trend of mean age at the first union, just a little older. At first, this result seems logical, as a consequence of the marital fertility. However, Latin America has a considerable proportion of non-marital fertility (LAPLANTE et al., 2015), which prompts an alternative explanation: the same factors at micro and macro levels that lead to early union formation also lead to early pregnancy. For example, in a context of greater distance from formal institutions, both unions can form earlier as an economic protection strategy, and fertility can appear earlier due to the lack of access to contraceptive methods. Lima et al. (2018) discuss the heterogeneity of the age pattern of fertility in the region, which also appears in our results. 
FIGURE 2

Mean age of women at the transition to adulthood, at entry into the labor market, at the first union, and at the first child Latin America countries - 1960-2010

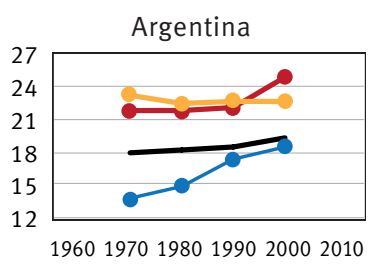

Chile

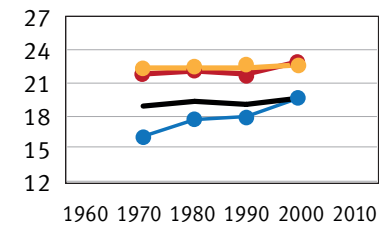

Ecuador

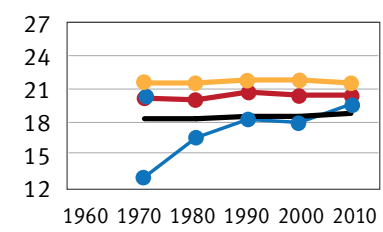

Mexico

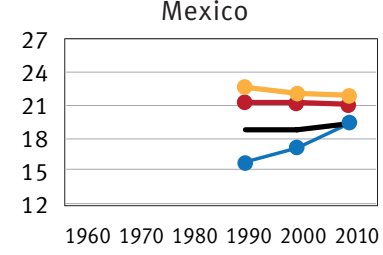

Paraguay

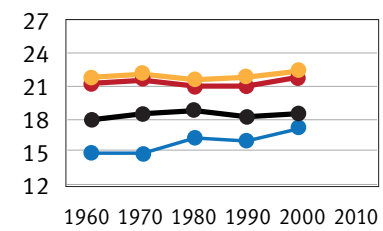

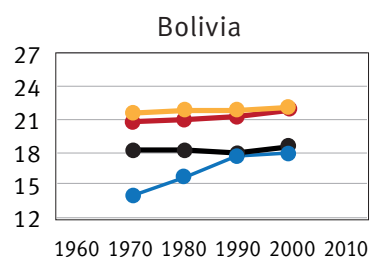

Colombia

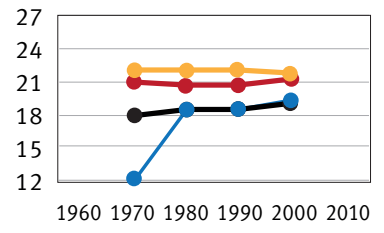

Guatemala
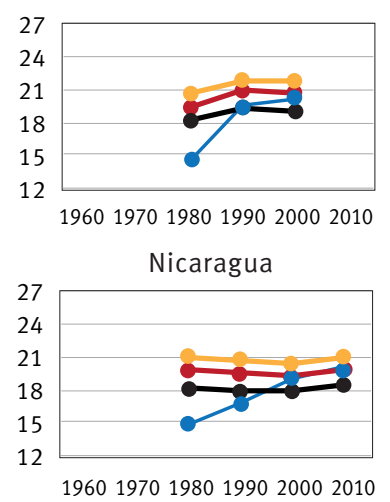

Uruguay

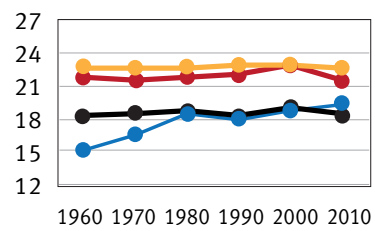

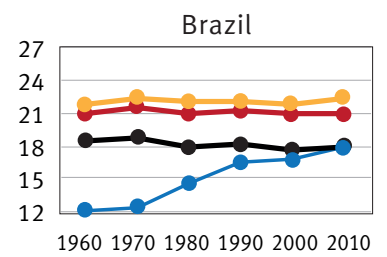

Costa Rica

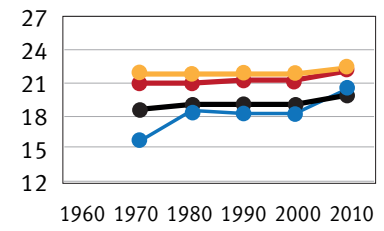

Honduras
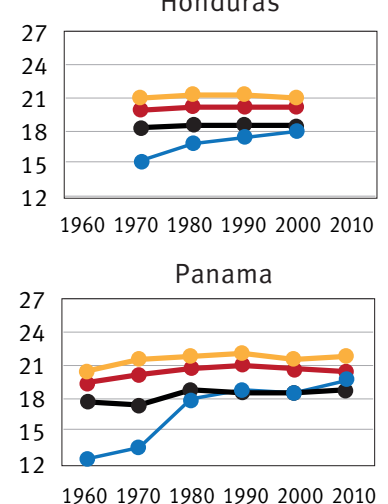

Venezuela

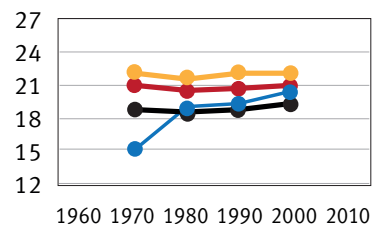

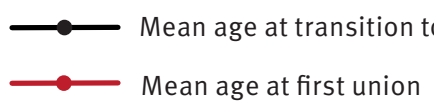

Mean age at entry into labor market

Mean age at first child

Source: IPUMS (2020).

The greater weight of family formation for the transition to adulthood among women and the stability of mean age at the first union and at first child would explain the stability of the mean age at the transition to adulthood of Latin American females. This hypothesis corroborates the increase in mean age at entry into the labor market despite the maintenance of mean age at transition to adulthood. 


\section{Conclusion}

This research note sought to present the Latin American context of transition to adulthood. Most of the previous research focusing on more developed countries indicate a delay in transition to adulthood. We contributed to the analysis of transition to adulthood by looking at different dimensions of the transition whereas previous studies focused on the transition to marriage or trends in fertility. In this paper, we found a movement to postpone the transition to adulthood in Latin America in the second half of the 20th century. We observed that this movement of postponement was stronger for males, while the mean age at the transition to adulthood among females was fairly stable in the period analyzed in almost all countries. A possible explanation for this result could be the difference in the transition of males and females concerning the catalyst event: men would tend to transit to adulthood by entering the labor market and women by forming a new family, as observed before (FUSSEL; PALLONI, 2004). As a result, postponing entry into the labor market due to increased schooling and policies to limit child labor was more effective in delaying transition to adulthood among men than among women. Transition to adulthood of men in Latin America is affected by what Corijn and Klijzing (2001) identify as the institutionalization of the transition to adulthood: it was postponed by increasing the legal restrictions on the transition via entry into the labor market. The transition of women was less affected by institutionalization, as their transition is still strongly linked to events that historically take place outside legal institutions, such as informal union and teenage pregnancy.

Mean age at transitions in Latin America is lower than that reported in the US (FUSSEL et al., 2007) and Europe (BILLARI, 2004), which might be explained by the early family formation and younger entry into the labor market due to a lower rate of entry into higher education. Transition to adulthood in Latin America was expected to be closer to that described in countries like Portugal, Spain, and Italy due to cultural heritage. However, these countries, classified as familistic (MAYER, 2001; BILLARI, 2004), have the latest transitions in Europe, especially concerning family formation. We hypothesize that this cultural heritage is attenuated by the greater economic vulnerability and distance from legal institutions among Latin American families, which forces young people to work earlier and allows them to form families sooner. As a region in which the women's consolidation movement in the labor market is still ongoing, gender inequality also plays a role in advancing the transition to women's adulthood by discouraging them from pursuing a career in the labor market. An interesting hypothesis is that wealthier families can protect their children from economic vulnerability, and perhaps some familistic cultural heritage will prevail among them.

We also emphasize that there are limitations in the database, but census data are still the main source of data for studying the population of Latin America from a cross-country perspective and over long periods of time. The purpose of this note is not to analyze the transition for each country, or even the difference between them, but rather to present an 
overview of the theme on the region. One-country studies are essential to fill these gaps, even by using unique data sources from each country.

Thus, this brief research note brings two main contributions. The first is to locate Latin America as a whole in the discussion about postponing or advancing the transition to adulthood. The second, and more important, is to encourage new studies to better understand the particularities of the transition to adulthood in the continent and its population subgroups. Latin America is a region marked by strong inequalities, and the results for the total population shown in this paper certainly conceal socioeconomic disparities that, once clarified, will help understand transition in the continent better.

\section{References}

BARROS, R. P.; MENDONÇA, R.; DELIBERALLI, P.; BAHIA, M. O trabalho doméstico infanto-juvenil no Brasil. Boletim do Mercado de Trabalho - Conjuntura e Análise, n. 17, p. 21-30, 2001.

BILLARI, F. C.; LIEFBROER, A. C. Towards a new pattern of transition to adulthood? Advances in Life Course Research, v. 15, n. 2-3, p. 59-75, 2010.

BILLARI, F. C.; HIEKEL, N.; LIEFBROER, A. C. The social stratification of choice in the transition to adulthood. European Sociological Review, v. 35, n. 5, p. 599-615, 2019.

BILLARI, F. C.; LIEFBROER, A. C. Should I stay or should I go? The impacts of age norms of leaving home. Demography, v. 44, n. 1, p. 181-198, 2007.

BILLARI, F. C.; MANFEDI, P.; VALENTINI, A. Macro-demographic effects of the transition to adulthood: multistate stable population theory and an application to Italy. Mathematical Population Studies, v. 9, n. 1, p. 33-63, 2000.

BILLARI, F. C.; TABELLINI, G. Italians are late. Does it matter? In: SHOVEN, J. Demography and economy. Chicago: Universiyt of Chicago Press, 2010.

BILLARI, F. C. Becoming an adult in Europe: a macro(/micro)-demographic perspective. Demographic Research, v. 3, n. 2, p. 15-44, 2004.

BILLARI, F. C. The analysis of early life courses: complex descriptions of transitions to adulthood. Journal of Population Research, v. 18, n. 2, p. 119-142, 2001.

BUCHMAN, M. The script of life in modern society. Entry into adulthood in a changing world. Chicago: The University of Chicago Press, 1989.

CORIJN, M.; KLIJZING, E. Transition to adulthood in Europe: conclusions and discussion. In: CORIJN, M.; KLIJZING, E. (ed.). Transition to adulthood in Europe. Amsterdam: Springer, 2001.

ESTEVE, A.; LÓPEZ-RUIZ, L.; SPIJKER, J. Disentangling how educational expansion did not increase women's age at union formation in Latin America from 1970 to 2000. Demographic Research, v. 28, article 3, p. 63-76, 2013.

FUSSEL, E.; GAUTHIER, A.; EVANS, A. Heterogeneity in the transition to adulthood: the cases of Australia, Canada and the United States. European Journal of Population, v. 26, n. 3, p. 389414, 2007.

FUSSEL, E.; PALLONI, A. Persistent marriage regimes in changing times. Journal of Marriage and Family, v. 66, n. 5, p. 1201-1213, 2004. 
GRANT, M. J.; FURSTENBERG, F. F. Changes in the transition to adulthood in less developed countries. European Journal of Population, v. 23, n. 3-4, p. 415-428, 2007.

HAJNAL, J. Age at marriage and proportions marrying. Population Studies, v. 7, n. 2, p. 111-136, 1953.

HEATON, T. B.; FORSTE, R.; OTTERSTROM, S. Family transitions in Latin America: first intercourse, first union and first birth. International Journal of Population Geography, v. 8, n. 1, 2002.

LAPLANTE, B.; CASTRO-MARTÍN, T.; CORTINA, C.; MARTÍN-GARCÍA, T. Childbearing within marriage and consensual union in Latin America, 1980-2010. Population and Development Review, v. 41, n. 1, p. 85-108, 2015.

LESTHAEGHE, R. The second demographic transition, 1986-2020: sub-replacement fertility and rising cohabitation - a global update. Genus, v. 76, n. 10, 2020.

LESTHAEGHE, R. The unfolding story of the second demographic transition. Population and Development Review, v. 36, n. 2, p. 211-251, 2010.

LIMA, E.; ZEMAN, K.; SOBOTKA, T.; NATHAN, M.; CASTRO, R. The emergence of bimodal fertility profiles in Latin America. Population and Development Review, v. 4, n. 44, 2018.

LLOYD, C. (ed.). Growing up global: the changing transitions to adulthood in developing countries. Washington: The National Academic Press, 2005.

MAYER, K. U. The paradox of global social change and national path dependencies: life course patterns in advanced societies. In: WOODWARD, A. E.; KOHLI, M. (ed.). Inclusions-Exclusions. London: Routledge, 2001.

IPUMS. Minnesota Population Center. Integrated public use microdata series international: version 7.2. 2020.

MODELL, J.; FURSTENBERG, F.; HERSHBERG, T. Social change and transitions to adulthood in historical perspective. Journal of Family History, v. 1, n. 1, p. 7-32, 1976.

NEIDHÖFER, G.; SERRANO, J.; GASPARINI, L. Educational inequality and intergenerational mobility in Latin America: a new database. Journal of Development Economics, v. 134, p. 329-349, 2018.

SIRONI, M.; FURSTENBERG, F. Trends in the economic independence of young adults in the United States: 1973-2007. Population and Development Review, v. 38, n. 4, p. 609-630, 2012.

VERONA, A. P.; DIAS JÚNIOR, C.; MIRANDA-RIBEIRO, P.; FAZITO, D. First conjugal union and religion: signs contrary to the second demographic transition in Brazil? Demographic Research, v. 33, p. 985-1014, 2015.

WACHTER, K. Essential demographic methods. Cambridge: Harvard University Press, 2014.

\section{About the authors}

Matheus Menezes dos Santos is a Ph.D. Candidate in Demography at Centro de Desenvolvimento e Planejamento Regional (Cedeplar), Universidade Federal de Minas Gerais (UFMG).

Bernardo Lanza Queiroz is Associate Professor of Demography at Centro de Desenvolvimento e Planejamento Regional (Cedeplar), Universidade Federal de Minas Gerais (UFMG).

Ana Paula de Andrade Verona is Associate Professor of Demography at Centro de Desenvolvimento e Planejamento Regional (Cedeplar), Universidade Federal de Minas Gerais (UFMG). 


\section{Contact address}

\section{Matheus Menezes dos Santos}

Universidade Federal de Minas Gerais, Faculdade de Ciências Econômicas, sala 2096 Avenida Antônio Carlos, 6627, Pampulha

31270-901 - Belo Horizonte-MG, Brazil

\section{Bernardo Lanza Queiroz}

Universidade Federal de Minas Gerais, Faculdade de Ciências Econômicas, sala 2096 Avenida Antônio Carlos, 6627, Pampulha

31270-901 - Belo Horizonte-MG, Brazil

\section{Ana Paula de Andrade Verona}

Universidade Federal de Minas Gerais, Faculdade de Ciências Econômicas, sala 2096 Avenida Antônio Carlos, 6627, Pampulha

31270-901 - Belo Horizonte-MG, Brazil

\section{Resumo}

Transição para a vida adulta na América Latina: 1960-2010

A transição para a vida adulta é um tema pouco explorado de forma multidimensional na América Latina. Este artigo busca descrever e caracterizar o processo de mudança na transição de homens e mulheres na região, entre 1960 e 2010. Utilizando dados censitários fornecidos pela plataforma IPUMS para 15 países latino-americanos, foram calculadas as idades médias na transição para a vida adulta, no ingresso no mercado de trabalho, na primeira união e no nascimento do primeiro filho. Conclui-se que houve um processo de postergação da transição para a vida adulta, porém, foi muito mais forte para os homens do que para as mulheres, o que pode ser atribuído aos acontecimentos ligados à transição de cada grupo. Com esses resultados, esperamos encorajar mais investigações sobre a transição para a vida adulta na América Latina.

Palavras-chave: Transição para a vida adulta. Juventude latino-americana. Idade média de entrada no mercado de trabalho. Idade média na primeira união. Idade média ao nascimento do primeiro filho.

\section{Resumen}

Transición a la adultez en América Latina 1960-2010

La transición a la adultez es un tema poco explorado de manera multidimensional en América Latina. Este artículo busca describir y caracterizar el proceso de cambio en la transición de hombres y mujeres en la región entre las décadas de 1960 y 2010 . Utilizando datos censales proporcionados por la plataforma IPUMS para 15 países de América Latina, calculamos las edades medias en la transición a la edad adulta, entrada al mercado laboral, primera unión y primer nacimiento. Concluimos que hubo un proceso de postergación de la transición a la adultez que fue mucho más fuerte para los hombres que para las mujeres, lo que atribuimos a los hechos relacionados con la transición de cada grupo. Con estos resultados esperamos impulsar nuevas investigaciones sobre la transición a la vida adulta en América Latina.

Palabras clave: Transición a la adultez. Juventud latinoamericana. Edad media de ingreso al mercado laboral. Edad media de la primera unión. Edad media al primer nacimiento. 